\title{
Pastoral theological reflections on caregiving and religious pluralism
}

\section{Reflexões teológico-pastorais sobre cuidado e pluralismo religioso}

\section{Kathleen Greider}

Doctor, senior staff clinician and supervisor at The Clinebell Institute and also professor of Pastoral Care and Counseling at Claremont School of Theology and Professor of Religion at Claremont Graduate University, Claremont, California - USA, e-mail: kgreider@cst.edu

\section{Abstract}

In this essay, I take up the topic of what is required of religious caregivers to "open up" to persons of different faiths. ${ }^{1}$ Religious pluralism is a crucial focus for reflection on caregiving because of the obvious increase in recent years of interreligious encounter

1 This is a modified version of a paper presented at the 22nd International Seminar of the Society for Intercultural Pastoral Care and Counseling (SIPCC), in September 2010 in Strasbourg, France. The theme of the Seminar was "Dynamics of Migration Today: Pastoral Care and Counseling in a Socio-Political and Cultural Context". Given that the dynamics of migration include increased contact between people of different religions, I was asked by the conference organizers to address how religious caregivers can "open up" to people of other faiths. The participants in the seminar were religious caregivers in a variety of positions from approximately twenty countries. All identified in some way with Christianity, though they undoubtedly locate themselves in a great plurality of positions on the spectrum of diverse theological opinion and spiritual practice we call Christianity. For more information, visit the SIPCC website: <http://www.ekir.de/sipcc/fr_set_engl-stras-start1.htm>. 
in everyday life and in the practices of caregiving. I explore this topic, first, by making explicit some of the challenges inherent in interreligious caregiving. This is an important first step in light of the risks of romanticism and simplification with regard to openness and interreligious care. In the remainder of the essay, from my religious location within Christianity, I offer pastoral theological reflections on caregiving in light of religious pluralism by means of two methods commonly employed in the field: self-reflexivity and reflection on a specific relationship of care.

Keywords: Religious pluralism. Religious caregivers. Openness. Self-reflexivity. Care. Theology.

\section{Resumo}

Neste ensaio, discuto a necessidade de os cuidadores se "abrirem" a pessoas de diferentes credos. O pluralismo religioso tem se tornado um foco crucial na reflexão sobre cuidado e aconselhamento em função do evidente aumento, nos últimos anos, dos encontros inter-religiosos na vida cotidiana e na prática do cuidado. Exploro este tema explicitando, primeiramente, alguns dos desafios inerentes à prática do cuidado e aconselhamento inter-religioso. Este é um primeiro passo importante em função dos riscos de romantização e simplificação em relação ao "abrir-se" e ao cuidado inter-religioso. Em seguida, a partir do meu lugar dentro do Cristianismo, proponho reflexões teológicas sobre o cuidado à luz do pluralismo religioso por meio de dois métodos comumente empregados neste campo: a autorreflexividade e a reflexão sobre uma relação de cuidado específica.

Palavras-chave: Pluralismo religioso. Cuidadores religiosos. Abrir-se. Autorreflexividade. Cuidado. Teologia.

\section{Challenges of caregiving in interreligious relationships}

The possibility of offering care in the context of religious pluralism presents immediate challenges. First, the topic is wonderfully and maddeningly ambiguous. For example, what qualifies us to be called "open"? 
Like the door to our home, shop, or church, the door to our minds and hearts can be wide open, or halfway open, or barely ajar, left open accidentally or intentionally. All these forms of openness suggest different degrees - and qualities - of openness. The ambiguity of openness can also be attributed to the fact that it is constituted by the best aspects of both our naivete and our wariness - thus, the memorable phrase attributed to Jesus: "be wise as serpents and innocent as doves" (Mt. 10:16 NRSV). The spiritual demands of integrating wisdom and innocence on a daily and consistent basis tax the most spiritually mature persons. It is not difficult to think of well-meaning persons - others, ourselves - who actively cultivate openness and still hurt persons of religious identities different than our own. The harm done may be severe or slight. In either case, we are reminded that our openness brings us into relationship with the tender and tough religious sensibilities of others. Once our openness has brought us that far, navigating such a complex relationship requires knowledge and spiritual grace not gained through will or good intentions alone.

Closely related is a second challenge - that religion can be used to harm as well as to help is arguably the most profound dimension of the ambiguity of trying to relate religious pluralism and caregiving. As we affirm the possibilities of care in religious pluralism, we must just as faithfully and rigorously cultivate consciousness that even though we think we are using religion to help, we may harm. Again, the harm done may be severe or slight. In either case, the harm adds to centuries of violence and alienation between religious communities. Given the long history during which religions have been deformed by use of them to rationalize violence, we have accomplished only basic decency and the most obvious requirement of non-violence if we have managed to curb our physical violence. We must continue on in our commitment to non-violence, ferreting out how our thoughtlessness, attitudes, and behaviors sometimes do violence in the communal, interpersonal, and psycho-spiritual dimensions of interreligious relationship.

A third challenge when considering what is required of religious caregivers to open up to people of other faiths relates to the diversity of opinion about what constitutes "care". The integrity of our inquiry into how we can be caregivers to persons of other faiths depends on honesty 
about the differences within religious traditions about how open we are required to be in order to be caring. Arguably the most acute questions relate to the truth, holiness, and transformative possibilities of diverse traditions. In Christianity, some Christians say that they can assess their religious tradition as superior to other religions and at the same time offer care that is experienced as such. Other Christians say that assessing one's religion as superior is inherently an uncaring stance toward persons of other religions, that the most profound care requires a non-judgmental stance that affirms the religious commitments of those to whom care is offered. My descriptions of these positions are somewhat caricatures, but they point to the extreme differences within Christianity regarding the interplay of religious difference and caregiving.

There is voluminous support in Christianity for both positions and many in between, and this fact leads to a fourth challenge: there is biblical support and theological exposition to support whatever opinion Christians hold relative to religious pluralism, so what shall we say is the basis for our positions? The different and often vehement positions we take relative to the value of religious pluralism seem to boil down not much to choice but the dynamism of our different life histories and the mystery of how any spiritual path is shaped. This being the case, caregiving in interreligious relationship is a challenging subject because it is very personal and often contentious. This is true not least among my people, Christians, since it so often leads to intractable and excruciating painful arguments that our religion is or is not superior to others. In my experience among Christians, the topic of this essay is more likely to lead to judgmentalism and division than to openness. What have we accomplished if our theology allows us to open up to one degree or another to people of other faiths, but not to people of our own faith with whom we are in disagreement?

Finally, a fifth challenge relates to methodology. The responsibility of being educated in the theories and methods of pastoral theology and care includes, among other things, the obligation to speak contextually and self-reflexively as well as for the purpose of care. On the one hand, practical theologians must aim to develop theology that arises from and speaks to the actual, specific, personal, chaotic, and compromised conditions of human living as we have experienced it. This honesty and particularity 
about the complexity of human experience includes self-reflexivity and a degree of transparency about our personal and social locations - our own experience of the actual, specific, personal, chaotic, and compromised conditions of human living. Academic, political, or civic engagement with religious pluralism can be conducted at the level of the abstract, generalized, or ideal. In contrast, pastoral theological engagement with religious pluralism must be grounded in the concrete, particular, and real. On the other hand, pastoral theologians are responsible to speak in ways that privilege the requirements and responsibilities of care. As religious caregivers, we are charged to care for the traditions of which we are representatives, but even more so for the people and communities we encounter in our work. Though we may not agree on what constitutes care for human beings, it is clear that the responsibilities of pastoral theologians and religious caregivers are somewhat different from, for example, those who are called to clarify doctrinal orthodoxy or preserve religious institutions.

Given these combined challenges, it is clear to me as a pastoral theologian and caregiver that this topic - so full of ambiguity, complexity, and danger - cannot be addressed appropriately as if it were an objective matter with generalizable options for response. Fortunately, methods in pastoral theology and care take just these conditions into account. We construct theology and shape our practices with full awareness of the necessity of particularized and partial reflections on the human condition, and with full confidence in the value and persuasive power of every human life. In the following sections, as a means of reflecting on how religious caregivers can open themselves to persons of others faiths, I will employ two widely endorsed methods in pastoral theology and care: selfreflexivity and reflection on a specific relationship of care

\section{Reflections on caregiving and religious pluralism: the pastoral theological method of self-reflexivity}

In my pastoral and personal experience, theologies that open religious caregivers to people of other faiths result from one's particular life narrative, especially one's spiritual path and formation. The degree and 
qualities of our openness to people of other faiths are partially a result of our own choices but arguably just as much a result of happenstance and our response to it - the synchronicity of the family and communities into which we are born, the religious culture we inherit, the teachers that cross our path, the interreligious relationships we build. As a pastoral theologian, I would not - because I cannot - tell you what theology will open you up to persons of other faiths. To put it theologically, we can say that it is finally a matter that each of us must work out within our own religious framework and within relationships with persons of other religions.

I can, however, through the method of self-reflexivity, offer reflection on some of what has happened in the synchronicity of my life narrative to open me up to people of other religions. ${ }^{2}$ The field of pastoral theology and care places a high value of self-reflexivity in academic and professional discourse because, as a mode of transparency, it makes the personal bases and biases of our theological assertions more accessible to our readers. Therefore, I offer these reflections for the purpose of honesty about the subjectivity of my approach to religious pluralism and care. I do not presume that my choices, rationale, and beliefs are or should be your beliefs. I offer my self-reflexivity to you in the spirit of openness to religious pluralism.

For as long as I can remember, I have been seeking to comprehend, love, and respond to what I have come to call Divine Mystery - the mystery many people call G-d. ${ }^{3}$ Relative to religious pluralism, it is crucial for me to remain mindful that though my search for the Divine Mystery began in Christian community, in the beginning, I did not choose Christianity, it was chosen for me. Christianity is the religion of my ancestors, as far back as I know, and so Christianity was chosen for me by my parents, and their parents before them, and so on. My Christian identity remains to this day partially an accident of birth. I was baptized into the Christian church as an infant. I was taught the Christian language - it became my

2 I could offer reflections as well on what is happening, what continues to open me to other people of faith. However, given the limitations of space, I choose to focus on my youth and young adulthood, as these periods were most formative for me with regard to openness to religious pluralism and care.

3 It is my custom to use the formulation "G-d" to refer to divinity, rather than spelling the word in its entirety. Following its use in Judaism, this incomplete spelling symbolizes the humility we are advised to practice when speaking of the divine and the incapacity of humans to know the divine completely.

Rev. Pistis Prax., Teol. Pastor., Curitiba, v. 3, n. 2, p. 449-465, jul./dez. 2011 
first religious language, my native spiritual tongue. Through the Christian language, my whole being was shaped. Christian stories, ideas, values, and practices were primary in the ecology in which grew - it was like the air I breathed, the food I ate, the love in which, as a dependent vulnerable child, I had no choice but to trust. I grew to love the G-d and Jesus I was given.

Of course the Christian church can be likened to the vast geography of this planet and the diverse peoples that inhabit it. I was born and reared in the Evangelical United Brethren region of Christianity. The orthodox and pietistic beliefs of that denomination nourished and sustained me for my earliest years. But for reasons I cannot fully explain, very early I was filled with what for me were questions, though something gave me the impression that my elders experienced them as doubts. The only vivid memory I have of Sunday church school was of raising my hand to ask for an explanation of miracles and of the teacher who responded with a blank look and a painfully long silence before he could find words. By the time I was nine years of age, my question about one type of miracle was especially persistent: "exactly how did Jesus heal the sick?" I was disquieted by healing stories. I had been taught that the G-d I had been given is omnipotent, omniscient, and omnipresent. This conveyed that the G-d given to me was choosing not to heal my mother, who was seriously ill, and not getting better. Later I learned that some of the Christian leaders around my family, including our pastor, held the belief that her illness was a result of her insufficient faith. I was deeply troubled by this response, which struck me as dangerously self-righteousness and a failure of respect and compassion, especially since I had no memory of their relating to us much at all. This very common struggle - to make sense of the co-existence of suffering, the hard-heartedness of religious people, and a powerful, loving G-d - was the first aspect of my life experience that began to open me up to other religious possibilities. I was also troubled at a young age by the call to evangelize others: I distinctly remember refusing to hand out religious literature on a city street corner because it seemed to me much like what was offered to my family - Christian judgment and a failure of respect and compassion, on the basis of no real relationship.

I had no significant exposure to religions other than Christianity until I was a college student. Through this exposure, I arrived at a second 
aspect of experience that continued to open me to people who belonged to other religions and to those of no religion at all. I learned about and met people living what my Christian community called "spirit-filled lives," even though they were not Christians. They were doing the good work that I had come to think was the fruit of a Christian life. But it was clear that people outside the Christian church had passion and commitment and brilliance and love to build the kingdom of G-d on earth, more so than some Christians I knew. Yet all I had been taught to that point was that these good people would be condemned by G-d, because they were not Christian. This second aspect of experience - the Christian church's assertion that people whose lives were marked with the holiness to which Christianity taught me to aspire would still be condemned - became a second arena in which I was left deeply troubled by what I could experience only as a lack of Christian humility and compassion.

In my early twenties these experiences brought me to a turning point in regard to my openness to people of other religions. I was faced with a choice that has been presented to many Christians: choose to believe that G-d condemns good people because they aren't Christian or find another way. This turning-point was both disconcerting and clear for me. It was clear that I would not, could not, surrender my love of G-d to Christian doctrine. In my own devotions I had come to know G-d to be endless love, disciplined mercy, and ultimate compassion. Also, this condemnation seemed ludicrous to me, since Jesus was not a Christian. It was disconcerting, though, because at the time I did not know if my refusal to join in the condemnation of people outside the Christian church meant that I was no longer a Christian. Not long after, I continued my search for Divine Mystery by going to theological school, where I learned that there were other Christians who were troubled by this and similar choices.

Finally, I will share beliefs that have evolved to be a foundation for the degree of openness and kind of care I am called to offer in light of religious pluralism. These beliefs have grown out of my encounter with the diversity within Christianity, with people of other religions, and with people who choose no religion. I grasp and practice these beliefs imperfectly, but they orient my life and I have found them fully trustworthy. I could make substantial arguments for each of these. Given the limits of 
space, however, I can only list them, though with some attention to their logical relation.

- Most fundamentally: That which is sacred and holy is a Divine Mystery never fully comprehended by human beings.

- My first loyalty is to this sacred and holy Divine mystery, as the origin of the gift of all life, and of my particular life. Therefore, my first loyalty is to not to any particular religion, denomination, congregation, or human leader but to Divine Mystery.

- Because Divine Mystery passes all human understanding, to name it - whether as Divine Mystery, G-d, YHWH, Jehovah, Adonai, I AM WHO I AM - or to speak of it in any way is to risk arrogance. Therefore, humility is the condition of my right to speak of it at all. And, to think or make definitive statements about Divine Mystery, as if we fully know the Divine Mystery, to think or speak in any way that forecloses on the possibility we are mistaken, is blasphemy.

- Divine Mystery is and has been present at all times and its power shared with the whole creation, including humanity. All creation, which includes all religions, has the potential to be a means by which Divine Mystery can be glimpsed and can be distorted. All humanity and all religions have used the power of Divine Mystery for evil and for good. No religion can fully contain or express the Divine Mystery.

- Human life has meaning and humans are saved from ultimate destruction by devotion to Divine Mystery, demonstrated through, as the Hebrew Bible puts it, the essentials of kindness, justice, and humility (Mic. 6:8). I cannot earn and or repay the gift of my life. I can, however, honor this gift by living with gratitude and by protecting the gift of life wherever it is found.

- Human life is at least as sacred as human institutions, such as religions, especially where human life is squandered through suffering and unnecessary violence.

- My primary teacher is the Jew and rabbi, Jesus of Nazareth. The Jewish life and teaching of Jesus was the primary inspiration for 
the formation of Christianity and, finally, for my eventual choice to affiliate myself with Christianity.

- The Christian Church is a human and limited expression of Christianity.

- The Divine Mystery has no arms or legs but those of humanity (SÖLLE, 1978, p. 98-99). The Divine Mystery calls me into caregiving, to embody Divine Mystery as nearly as possible through responding to the suffering and joy of the creation, and seeking to curtail unnecessary violence.

- The biblical mandate to Christians to make disciples is best illuminated for me in the words of a Christian woman writer: "We convert, if we do at all, by being something irresistible, not by demanding something impossible" (SARTON, 1977, p. 57-58).

\section{Reflections on Caregiving and Religious Pluralism: The Pastoral Theological Method of Case Study}

I turn now to a second pastoral theological method as a means of responding to the question of what is required of us if we are to open up to people of other religions. Case study is one way to practice pastoral theological commitment to the capacity of any life situation, through our careful reflection on it, to be a source of wisdom, and perhaps of Divine Mystery. In this practice of close reflection on human experience, pastoral theologians and caregivers often choose narratives of actual people, perhaps people we meet in caregiving situations. However, we can also begin by reflecting on narratives that come from the human imagination. For our purposes, I have decided to use a story told on film as the basis of reflection. Since migration is a widespread contemporary phenomenon that has increased exponentially the amount of contact between persons of different religions, I have chosen to reflect on the film "The Visitor," in which migration plays a central role. The film does not explicitly address religious pluralism. It nonetheless offers rich material for our reflection because it is a story about deeply significant themes in spirituality: vulnerability and mortality, loss and grief, meanings and values, and how encountering 
persons different from us can set in motion profound changes in all the participants' lives. I will begin, as this method always does, with careful description of the human situation being considered, avoiding any interpretive comments unless offered by the persons directly involved. After the description, I will comment on three dimensions of human experience evident in this narrative that seem to contribute to openness.

\section{Description}

Walter Vale is a middle-aged white male who lives and works somewhere outside New York City. For twenty years, he has been an economics professor at a college in a small town. But Walter has long ago become disillusioned with the academic life. He has taught the same class with the same syllabus for as many years as he can remember. He is supposedly writing a book, but progress stopped years ago. When we meet him, Walter is also in grief, suffering from the death of his wife a few months earlier. Because she was a concert pianist, he is trying to learn the piano and often spends his time listening to classical music. Walter seems like he is sleepwalking through his life, all his emotion deadened. When a student troubled with personal problems tries to submit a paper late, Walter turns away the paper and the student brusquely, without empathy, even though Walter knows all too well what it is like to be troubled. When Walter's dean requires that he go to New York City to present a paper for a colleague who is under medical restrictions, Walter tries to refuse. Soon we learn that Walter does not want to go to the city because, before her death, he and his wife shared an apartment there. Walter has not relinquished the apartment, but he has not been there for many months. The Dean insists.

When Walter arrives at the apartment, he discovers that a young couple, Tarek and Zainab, has been living there for two months, having fallen prey to a real estate scam. Walter is very startled but manages to tell them politely that they must leave. Walter sits on the couch, watching impassively as they pack their belongings and struggle with their bags as they depart. Moments after they leave, he finds a picture they have forgotten to pack, a picture of the two of them together, happy. Suddenly, Walter 
is hurriedly walking down the street, trying to find them so he can return their picture. Walter finds them and in their brief conversation realizes they have nowhere to go. Something causes him to reverse himself. Walter invites Tarek and Zainab back to his apartment to stay there until they can find other lodging.

Tarek, like Walter's wife, is a musician, a drummer. The next day Walter comes back to the apartment and finds him practicing. Tarek invites Walter to join him in the drumming. Walter quickly refuses, but when Tarek persists, and offers to help him, Walter slowly sits and begins hesitantly tapping on a drum. Over the next few days, Tarek draws Walter into a world with rhythms different from any Walter had known before. He goes to hear Tarek's group play in a jazz club and joins Tarek in a drumming circle in the park. Walter hears Tarek's story of migration, of coming to the U.S. from Syria at a young age. With the encouragement of Tarek, Walter becomes a fairly good drummer. Just as noticeably, Walter becomes less isolated and shy, and smiles a bit more. A friendship seems to be developing between them.

One afternoon, Walter and Tarek are hurrying to catch a subway train. After paying for the ride, Tarek has trouble getting himself and his drum through the gate, so he jumps over the gate. The police, watching from nearby, use this as an excuse to detain and arrest Tarek, despite Walter's explanations and protests. Walter returns to the apartment and must tell Zainab that Tarek has been arrested. Though Walter is sure that Tarek will be released and everything will be okay, Zainab is terrified. They both are undocumented, she tells Walter: "It will not be okay".

Having been drawn into their lives, Walter is desperate to help them. He hires an immigration lawyer for Tarek. He visits Tarek at the detention center. When Tarek's mother, Mouna, arrives from Michigan, he hears the whole story of their migration - Mouna brought Tarek to the U.S. when he was very young to escape persecution in Syria; they both immigrated illegally in order to not to be sent back to the trouble in Syria; she and Tarek have lived in the U.S. for twenty years and she has worked hard for them to have a stable life and make many friends; like Tarek and Zainab, Mouna is undocumented. 
Now Walter cares for Mouna, as well. He invites her to stay at the apartment. Since she cannot enter the deportation center where Tarek is being held because she has no legal papers, Walter takes her there and carries her letters to Tarek inside for her. Walter introduces Mouna and Zainab. Walter and Mouna, both widowed, also find companionship and tenderness together.

But all Walter's efforts for this family are like a drop in a bucket. Within days and without warning, Tarek is deported to Syria. Walter screams at the deportation officials, realizing that his citizenship gives him no power to affect the situation. Zainab is heartbroken and disappears out of fear the police will find her because of her connection to Tarek. To help Tarek, Mouna returns to Syria, unsure whether safety awaits her there and sadly aware that she will never be allowed back in the U.S. and is losing the life she had forged. Now, Walter is alone again, except that he has the drums left behind after Tarek deportation. The closing shot of the film is of Walter, now a street musician, playing the drums in the subway. Over the space of ten days, Walter's perspective has been profoundly altered.

\section{Reflections on the Narrative}

In my view, the question of how to open up to people of other faiths is a question of spirituality at least as much as it is a question of doctrine. Genuine suffering and acute human need of lives created as part of the Divine Mystery can sometimes quite suddenly reveal the incompleteness of doctrine. Perhaps this is why a saying of the Dalai Lama -"My true religion is kindness" - is so often quoted. But kindness worthy of being called a true religion is not easily practiced. It requires spiritual resources and maturity and, even then, the spiritual demands of openness across borders are considerable. I am reminded of two friends who have participated in the New Sanctuary Movement by hosting in their home an undocumented woman, her husband, and their three children. They all lived together, two families under one roof, for eighteen months. Recently, one of the friends was talking about the cost of providing sanctuary to this family: she gave them sanctuary, she said, and thereby had lost her own 
sanctuary, the quiet refuge of her own home upon which she had previously depended for her spiritual life.

Because of the spiritual demands of openness and caregiving in situations of religious pluralism, I am deliberately trying to avoid the most commonplace concepts used in such discussions: for example, inclusivity, respect, welcome, hospitality, empathy, compassion. These are essential elements of our caregiving, of course. However, given the continuing plague of disrespect, rejection, hard-heartedness, self-orientation, and other forms of unnecessary violence, they seem not to be adequate by themselves. So, very briefly, through reflection on The Visitor, I will draw attention to three less commonly addressed aspects of openness to persons of other faiths: our emptiness, our strangeness, and our childlikeness.

Our Emptiness. Relative to our topic, a pivotal moment in the film comes when Walter reverses himself and invites Tarek and Zainab back to his home. What makes it possible for this to happen? When we meet Walter, he seems to be an empty man. The death of his wife seems to have been a psychospiritual tsunami, sweeping away not only his wife but also the rickety structures that comprised much of his life. Indeed, it seems perhaps this final assault has swept away all his life force. It is not that Walter is wallowing in his wounds. It is simply the case that his normal human grief has not run its course. He seeks comfort in the classical music she loved, but it does not fill him. When he tells Tarek and Zainab they must leave, he watches them from a distance, not unkindly but also in a disinterested, unmoved way. But when he finds the left-behind photo, the photo of them together and happy, he opens up a bit. He opens enough to try to find them to return the picture. Then, again engaged more closely into their situation, Walter invites them home.

This moment reminds us that our wounds can open us up. Henri Nouwen did us a good service by calling our attention to the wounded healer (NOUWEN, 1972). But we are in danger of misusing this concept. One way we misuse it is to continue to think of ourselves as healers, only now to think of ourselves as healers who are wounded. This is different than knowing that we are first and always wounded, able to "manage" our wounds and knowledgeable about healing perhaps, but not expert. I have always been sobered and helped by the well-known Buddhist koan about Nan-in, a Japanese 
master during the Meiji era (1868-1912), who received a university professor who came to inquire about Zen. Nan-in served tea. He poured his visitor's cup full, and then kept on pouring. The professor watched the overflow until he no longer could restrain himself. "It is overfull. No more will go in!" "Like this cup," Nan-in said, "you are full of your own opinions and speculations. How can I show you Zen unless you first empty your cup?"

Our Strangeness. In our search for how to open ourselves to people of other faiths, another pivotal moment in the film comes when for the first time Walter reaches for the drum. This moment builds on the first moment-Walter can reach for the drum in part because of his emptiness. Before the death of his wife, Walter was full of the ordinary and typical. When we learn he has taught the same economics course for twenty years, this suggests that there were likely numerous things Walter did that were very routine and unsurprising. But with the loss of his wife, the very heart of his routine is gone and strangeness takes over outside and inside Walter. When he hears Tarek's drumming, it seems it is a call to Walter's body, and he seems to be drawn by a magnetic force in the direction of this strangeness. But it is not Tarek's strangeness or the drum's strangeness that ultimately opens Walter. It is rather his willingness to risk encountering the strangeness in himself. When Tarek first invites him to play, we can see the inner struggle on Walter's face. Will I risk feeling uncomfortable? Will I allow myself to be vulnerable to this man I have just met, and allow him to be my teacher? Will I follow him out into his world, to jazz clubs and drumming circles in the park? Will I allow myself to feel not in charge, not knowledgeable, vulnerable?

As we reflect on migration and on how to open to people of other religions, we rightly give attention to the otherness of the migrant and the otherness of people of other religions. But their otherness is not the only or perhaps even the most difficult impediment to our openness. We can open ourselves to otherness only to the degree we can tolerate to encounter the strangeness in ourselves. Walter's blossoming happens not so much because he hospitably opens his home to Tarek, Zainab, and Mouna, but because once they are there, he allows himself to encounter the stranger in himself: we can imagine him asking himself, incredulously, "What am I doing living with strangers, drumming, making music in 
the streets?" Christians have heard Heb.13:2 countless times-"Do not neglect to show hospitality to strangers, for by doing that some have entertained angels without knowing it". In my hearing, the text has usually been a call to be hospitable to the strangeness of others. However, there is no reason that it cannot be considered a call to open ourselves to the strangeness in ourselves, and perhaps find there some Divine Mystery. Of course another text puts it plainly: "You shall also love the stranger, for you were strangers in the land of Egypt" (Deut 10:19).

Our Childlikeness. In our search for how to open to people of other faiths, a third pivotal moment comes when Walter is open enough to behave like a child. Again, this aspect builds on the previous ones: Walter, in his emptiness, is willing to try strangeness, and in this way, he finds in himself the fearlessness of the well-loved child. He is childlike when he plays the drums with Tarek and when he shyly joins the drumming circle in the park. And, when Tarek is suddenly deported, he is now open enough to throw a childlike tantrum. And with a teenager's sense of justice, Walter screams at the impassive immigration officers about Tarek's goodness and his life and the wrongness and unfairness of what as been done to his friend.

Since keeping ourselves closed to people of other religions is accomplished primarily through adult reasoning and strategies, our childlikeness will help us open up. If we can open up to our childlikeness, we will not be so discouraged if others in our tradition treat us like a naïve or misbehaving child for our openness to religious pluralism. If we can risk being childlike, we will be not only moved by the music of other religions, we will join in and try to learn the music loved by people of other religions. If we can give way to the child's need for love and fairness, we will be not only open to people of other faiths. We will be able sometimes to throw caution to the winds by demanding what in this world seems almost impossible: equity with our religious sisters and brothers and an end to killing in the name of religion.

\section{Conclusion}

The story of Walter, Tarek, Zainab, and Mouna is a reminder that it is not always clear who is visitor and who is host. It also is an encouragement 
that we can be gracious whether we are host or visitor, if we allow ourselves to be opened to our own emptiness, strangeness, and childlikeness. Similarly, all of us are migrants, traveling in the presence of Divine Mystery. Our openness to and caring for people of other faiths will depend ultimately on our openness to Divine Mystery, the otherness that matters most of all.

\section{References}

NOUWEN, H. J. M. The wounded healer: ministry in contemporary society. New York: Doubleday, 1972.

SARTON, M. The house by the sea. New York: Norton, 1977.

SOCIETY FOR INTERCULTURAL PASTORAL CARE AND COUNSELING SIPCC. Program materials for 22nd International Seminar: "Dynamics of Migration Today: Pastoral Care and Counseling in a Socio-Political and Cultural Context". Available in: 〈http://www.ekir.de/sipcc/fr_set_engl-stras-start1.htm〉. Access in: December 17, 2010.

SÖLLE, D. Death by bread alone. Translation David L. Scheidt. Philadelphia: Fortress, 1978.

THE VISITOR. Mccarthy, Tom, director. USA: Alliance Films. 2008. (1h48 min.), son., color.

Recebido: 21/12/2010

Received: 12/21/2010

Aprovado: 20/01/2011

Approved: 01/20/2011 